Jurnal Akuntansi dan Investasi, Vol. 19 No. 1, Hlm: 54-63 Januari 2018

Artikel ini tersedia di website: http://journal.umy.ac.id/index.php/ai

DOI: $10.18196 /$ jai.190191

\title{
Economic and Psychological Approach to Increase Tax Compliance in Micro, Small and Medium Enterprises
}

Tri Utami* and Susyanti

Faculty of Economics Universitas Widya Dharma, Klaten, Jawa Tengah, Indonesia

\begin{tabular}{l}
\hline A R T I C L E I N F O \\
\hline Article history: \\
received 19 Sept 2017 \\
reviwed 12 Okt 2017 \\
revised 20 Nov 2017 \\
accepted 20 Nov 2017 \\
Keywords: \\
Tax Compliance; The \\
Probability of Audit; \\
Profit; Guilt; Social \\
Stigma
\end{tabular}

\begin{tabular}{l}
\hline A B S T R A C T \\
The objectives of this study are to examine the economic (perceived probability to \\
audit and gain) and psychological (certainty, severity, social stigma, cynicism, guilty, \\
the fairness of law) factors that influence tax compliance. The data from this study is \\
obtained from the survey in 100 Micro, Small, and Medium Enterprises in Klaten \\
Regency, who are affected by Government Regulation no. 46 Year 2013 regarding \\
Final Income Tax for MSME possessing gross income less than IDR 4.8 billion per \\
year. Multiple Regression analysis is used to test the hypotheses. The result shows \\
that perceived probability to audit, stigma social and fairness of law are the factors \\
that influence tax compliance positively.
\end{tabular}

\section{INTRODUCTION}

The tax compliance aspect encourages taxpayers to always comply with all existing tax rules, as it is one of the largest sources of income for a country. Nevertheless, tax evasions often occur which could be caused by the lack of public confidence in tax funds management. Taxpayers could conduct it deliberately to reduce the amount of tax. No matter the reason from the perpetrators' side, tax evasion is a form of illegal behavior that involves an ethical dilemma. Therefore, increasing tax compliance is an important issue for countries where most of the country's expenditures are funded by taxes, such as Indonesia. It is known that $90 \%$ of the Indonesian State Budget comes from tax payments (Asnawi et al., 2009).

Increasing tax compliance could be conducted through economic and psychological approach. The economic approach could be conducted various ways, such as aggressive enforcement measures by sanctioning or auditing an institution or taxpayer allegedly tax evasion. In addition to the economic approach, increasing tax compliance can also be done with a psychological approach. An endeavor that could be done is giving a call to the taxpayer, therefore the taxpayer will feel guilty if he is involved in tax evasion. Another psychological approach that can be used to improve tax compliance is to provide friendly service (Chung and Trivedi, 2003).
The tax compliance study related to economic approach was conducted by Milliron and Toy (1988) which examined seven tax compliance factors consisting of deduction permitted, IRS information services, withholding and information reporting, the probability of auditing, preparer responsibilities, tax rates and taxpayer penalties. The above variables are grouped into two approaches: economic deterrence model and psychology paradigm. Research results concluded that the probability of audit is one of the determinants in tax compliance decisions.

Asnawi et al. Research (2009) examined the tax compliance using a randomized audit strategy and the probability of audit to determine a person's tax compliance behavior. Research result conducted by Asnawi et al. (2009) suggest that there is a significant correlation between random audit strategies, the probability of audit, and tax compliance.

Other studies related to the psychological approach were conducted by Beams et al. (2003) who examines the impact of motivating and deterrence variables on one's intent to conduct the stock sale and purchase transactions using insider trading. Motivational variables consist of profit, cynicism, and fair punishment. As for the deterrence variables consisting of custodial certainty, punishment consequences, social stigma, and guilt. The results exhibit insider information was conducted driven by profit and cynicism factors. 
On the other hand, insider information evasion was caused by guilt factor.

Based on Milliron and Toy (1988); Asnawi et al. (2009) and Beams et al. Research (2003), present study incorporating perceptual variables is likely to be audited with motivating and deterring variables. Beams et al. Research (2003) applied to insider trading cases and present research applied to tax compliance cases. Based on Asnawi et al. (2009) and Beams et al. (2003) research background, present research focuses not only on economic variables, but also considers the psychological factors capable to improve or decrease tax compliance. The present study will examine the effects of economic variables (probability of audit and profits) and psychological variables (cynicism, fair punishment, custodial certainty, punishment consequences, social stigma, guilt) towards tax compliance behavior. This study will also examine the probability of audit variables effect on tax compliance if moderated by profit and psychological variables.

Problem formulation described the main purpose of this study. First, to examine the probability of audit on tax compliance. Second, to determine the influence of economic and psychological variables on tax compliance. In order to determine factors that encourage a person to comply or avoid tax. This research ought to be conducted because it discusses factors affecting tax compliance which are complex matters. Economic factors, psychological factor, and human behavior ought to be considered. Research result is expected to provide evidence regarding tax compliance behavior in order to determine factors motivating and deterring tax compliance. Therefore the government can focus on measures to improve tax compliance.

\section{LITERATURE REVIEW AND HYPOTHESIS DEVELOPMENT}

\section{Tax Compliance}

Asnawi et al. (2009) state that tax compliance is a taxpayer's decision to abide by paying taxes in accordance with existing rules. Tax avoidance is making tax payments not equal to the amount that should be paid, either larger or smaller than appropriate. But most cases exhibit taxpayer reduce the amount of paid tax. Harinurdin (2009) defines tax compliance as the ideal condition of
Taxpayers who comply with tax laws and report their earnings accurately and honestly.

Tax evasion behavior could be conducted both deliberately and not deliberately, for example by manipulating financial statements. Tax disobedience can also be done due to psychological factors existing within an individual, such as the desire for profit or feelings toward unfair applied punishment (Beams et al., 2003). It can be concluded that one's psychological factors can affect one's behavior, in this case, is the behavior of tax compliance (Alm et al., 1992; Alm et al., 1995; Alm and Mc Kee, 1998).

\section{Economy Variables}

\section{Probability of audit}

A country with most of its funding comes from taxes, efforts to improve tax compliance are crucial. As an effort to determine a person's tax compliance, many previous research results indicate that a person's tax behavior is influenced by various factors as described by Alm (1995). These factors can be economic and non-economic factors. Other research results indicate that an individual is willing to pay taxes due to the fear of punishment. A large number of tax regulators use aggressive means such as auditing companies or individuals who are suspected of tax evasion and punish them accordingly.

The perception of a person's probability of audit is a condition that describes a person's feelings for audit. If someone fears to be audited, they possess a higher rate of tax compliance. When an individual/business entity financial statement received under the permitted threshold, the individual's will have a higher probability of audit. Previous research results prove that probability of audit can improve tax compliance (Milliron and Toy, 1988; Alm, 1988; Asnawi et al., 2009).

$\mathrm{H}_{1}$ : Probability of audit has a significant positive effect on tax compliance.

\section{Desire for Profit}

Profits are defined as the excess benefits over expenses incurred. Profits in the context of tax compliance are calculated by comparing the two different tax rates. High tax rates are a gap that can be entered by taxpayers who do not comply. When the tax rate is high then the profits to be gained will be greater (Ali et al., 2001). The taxpayer will react similarly whether tax rate is high 
or low. A high rate of tax compliance tend to occur during high tax rate, nevertheless taxpayer behave obediently. The greater a person desires to make a profit indicates higher tendency to conduct tax evasion.

$\mathrm{H}_{2 \mathrm{2}}$ : Desire for profits is negatively significant to tax compliance.

The perception of a person's probability of audit is a condition that describes a person's feelings for audits. If a person is afraid to be audited unexpectedly, it would increase their tax compliance. This condition will be different if the person is also faced with something that benefits him, in this case, is profit. Whether the probability of audit is low or high, desire for profit would deter tax compliance.

$\mathrm{H}_{2 \mathrm{~b}}$ : Interaction between probability of audit and desire for profit will negatively affect tax compliance.

\section{Psychology Variables}

\section{Cynicism}

Beams et al. (2003) states a variable called differential association. This variable is defined as aberrant behavior conducted by a number of people who can ultimately motivate others to engage in it. Salter et al. (2001) state that cynicism is an act of conduct motivated by self-interest. A cynic thinks that an act of offense conducted by another person may affect him, therefore one would think such action is permitted. Salter et al. (2001) conducted a study related to a person's tendency to behave. One of the independent variables in the study was cynicism. Research result exhibited that cynicism was significantly associated with fraud. It can be concluded that cynicism is an act of conduct in reference to others similar action. In the case of MSME, business perpetrators who have not paid tax according to the rules. Therefore cynicism can reduce tax compliance, an assumption that others conduct could be conducted by oneself.

$\mathrm{H}_{3 a}$ : Cynicism has a significant negative effect on tax compliance.

The perception of a person's probability of audit is a condition that describes a person's feelings for audits. If a person fears to be audited unexpectedly, it would increase their tax compliance. This condition will be different if a person is cynical. Despite high probability of audit, a cynical person would think that it would occur to other people. Hence the impact of auditing will no longer have an effect, and the presence of cynicism may reduce tax compliance.

$\mathrm{H}_{3 s}$ : The interaction between probability of audit with cynicism will negatively affect tax compliance behavior.

\section{Perception of Fair punishment}

Fair punishment is defined as one's consent to the law (Beams et al., 2003). Scott and Grassmick (1981) examined the effect of fair punishment perceptions on legal compliance. Research result exhibit that fair punishment perceptions have significant interaction effects on deterrence variables such as custodial certainty, severe punishment consequences, social stigma, and guilt. Mason and Calvin (1984) examined the relationship between fair punishment and tax compliance. Research result exhibits significant indirect effect between fair punishment and tax compliance.

$\mathrm{H}_{\mathrm{h}}$ : Perceptions of fair punishment have a significant positive effect on tax compliance.

The perception of a person's probability of audit is a condition that describes a person's feelings on audits. If a person fears to be audited unexpectedly, it would increase their tax compliance. The probability of audit perception and fairness of applied law would promote higher tax compliance rate. Thus fair punishment variable role is increasingly reinforcing probability of audit variables influence on tax compliance. It is expected that the interaction between audit possibilities with fair punishment can have a positive effect on tax compliance.

$\mathrm{H}_{\mathrm{t}}$ : The interaction between audit possibilities and perception of fair punishment has a positive effect on tax compliance.

\section{Custodial certainty}

Certainty referred to in this study is the certainty someone will be caught should be said person is conducting illegal acts (Beams et al., 2003). If someone feels there is certainty to be arrested, then someone will tend to obey the rules or the law. Custodial certainty has been exhibited to have a significant negative effect on one's intention to do evil (Grasmick and Green, 1980). The greater custodial certainty would increase law 
obedience. Based on the above description, the proposed hypothesis is:

$\mathrm{H}_{s a}$ : Custodial certainty has a significant positive effect on tax compliance.

The perception of probability of audit has a direction in line with the person's custodial certainty. When both probabilities of audit and custodial certainty rate are high, then taxpayer would deter from committing acts that violate tax rules. It is expected that the interaction between probability of audit with custodial certainty has a positive effect on tax compliance.

$\mathrm{H}_{s}$ : Interaction between probability of audit and custodial certainty have a significant positive effect on tax compliance.

\section{Punishment Consequence}

Grasmick and Green (1980) argue that punishment is generally grouped into three types: legal punishment, peer imposed punishment, and persistent guilt (self-imposed punishment). Legal punishment in this study is called the severity of punishment consequences. Several studies have exhibited that the severity of punishment has a significant negative impact on a person's intentions to engage in criminal behavior (Tittle, 1980). Weighing penalties have proven to be a significant deterrent factor in some experimental studies related to tax compliance (Beck et al., 1991). The more severe the punishment is would promote law compliance.

$\mathrm{H}_{6 \text { : }}$ : The severity of punishment consequences have a significant positive effect on tax compliance.

Audit result proved if financial report has been prepared based on existing standards or not. Higher probability of audit means higher uncovered errors or mistakes. Associated with the severity of punishment, it would promote law compliance.

$\mathrm{H}_{6 \mathrm{~b}}$ : The interaction between probability of audit and severity of punishment consequences has a positive effect on tax compliance.

\section{Social Stigma}

Other names of social stigma are peer imposed punishment. Social stigma is a sanction given by groups in social environment, for example, loss of attention / social environmental trust to individuals committing criminal acts (Beams et al., 2003). Punishment from community groups has been found to have significant deterrent effects (Grasmick and Green, 1980; Scott and Grasmick, 1981; Tittle, 1980). It can be concluded when a person feels threatened by group punishment would deter criminal actions.

$\mathrm{H}_{7 a}$ : Penalties from the social environment have a significant positive effect on tax compliance.

The social environment is the environment in which a person will stay and interact for a long time. Usually, people will give a long response to good or bad deeds committed. Bad deeds would receive longer negative response. High rate on probability of audit and social environment punishment would promote law compliance. This occurs due to a person's reluctance to receive negative response from immediate community. Especially should falsified financial statements are made public. Therefore the interaction between probability of audit and social stigma cause high rate of tax compliance.

$\mathrm{H}_{77}$ : The interaction between the probability of audit and social stigma has a positive effect on tax compliance.

\section{Guilt}

Self-imposed punishment is called guilt. Guilt is a punishment that comes from within the individual himself, for example, feelings of guilt for being involved in illegal and criminal acts. Previous research conducted by Grasmick and Green (1980); Tittle (1980) points out that guilt has a significant preventive effect on illegal behavior. If a person feels guilty when it comes to illegal acts, it is expected that the level of compliance with taxes will increase and ultimately noncompliance will decrease.

$\mathrm{H}_{8:}$ : Guilt has a significant positive effect on taxpayer behavior.

Guilt can prevent a person from taking illegal actions. Should one possess high rate on probability of audit and sense of guilt, then naturally it would promote law compliance. Therefore, the interaction between guilt and the probability of audit may increase tax compliance.

$\mathrm{H}_{8 s}$ : The interaction between feelings of guilt and probability of audit has a positive effect on tax compliance. 


\section{RESEARCH METHOD}

\section{Research Framework Model}

The research model implemented is described in the Figure 1.

\section{Data and Sample}

The data in this research was obtained through questionnaire survey technique e. The target population in this study was MSME entrepreneurs in Klaten District affected by Government Regulation no. 46 Year 2013 About Final Income Tax for MSME which have gross income less than IDR. 4,800,000,000.00 annually. The sampling technique was done by purposive sampling as much as +100 respondents in Klaten Regency.

\section{Variable Measurement}

Tax Compliance (COM), covering ideal conditions of Taxpayers who meet tax regulations and report their earnings accurately and honestly (Harinudin (2009); Asnawi et al., 2009). Tax compliance was measured by the instruments adopted from the Bobek et al. (2013) questionnaire with several additional questions.

Perception on Probability of audit (AU), includes the perception of how a person feels or fears if the financial statements that have been made will be audited. Instruments for measuring these variables were adopted from Asnawi et al.
(2010) which also developed from Milliron and Toy (1988) instruments.

Profit (GAIN), include perceptions for profit. Tax-abiding people will not react to existing tax rates/tax regulations (Ali et al., 2001). The instrument used to measure this variable was adopted from Beams et al. (2003). Cynicism (SIN), a cynic assumes that an act of violation by another person may affect him, so he considers it appropriate (Salter et al., 2001; Beams et al., 2003). The instrument used to measure this variable was adopted from Beams et al. (2003)

Fair punishment (FAIR), including a person's consent to the law (Beams et al., 2003). The instrument used to measure this variable was adopted from Beams et al. (2003). Custodial certainty (CERTAIN), includes the certainty that a person will be caught if the person commits a criminal act (Beams et al., 2003). Custodial certainty is measured with instruments adopted from Beams et al. (2003) with small amount of improvement. Punishment Consequences (PUNISH), including the weight of legal punishment (Grasmick and Green, 1980). The instrument used to measure this variable was adopted from Beams et al. (2003).

Social Stigma (STIG), including sanctions imposed by groups in the social environment, for example, loss of public concern/trust to individuals committing criminal acts (Grasmick and Green, 1980; Beams et al., 2003). The instrument used to measure this variable was adopted from Beams et al. (2003).

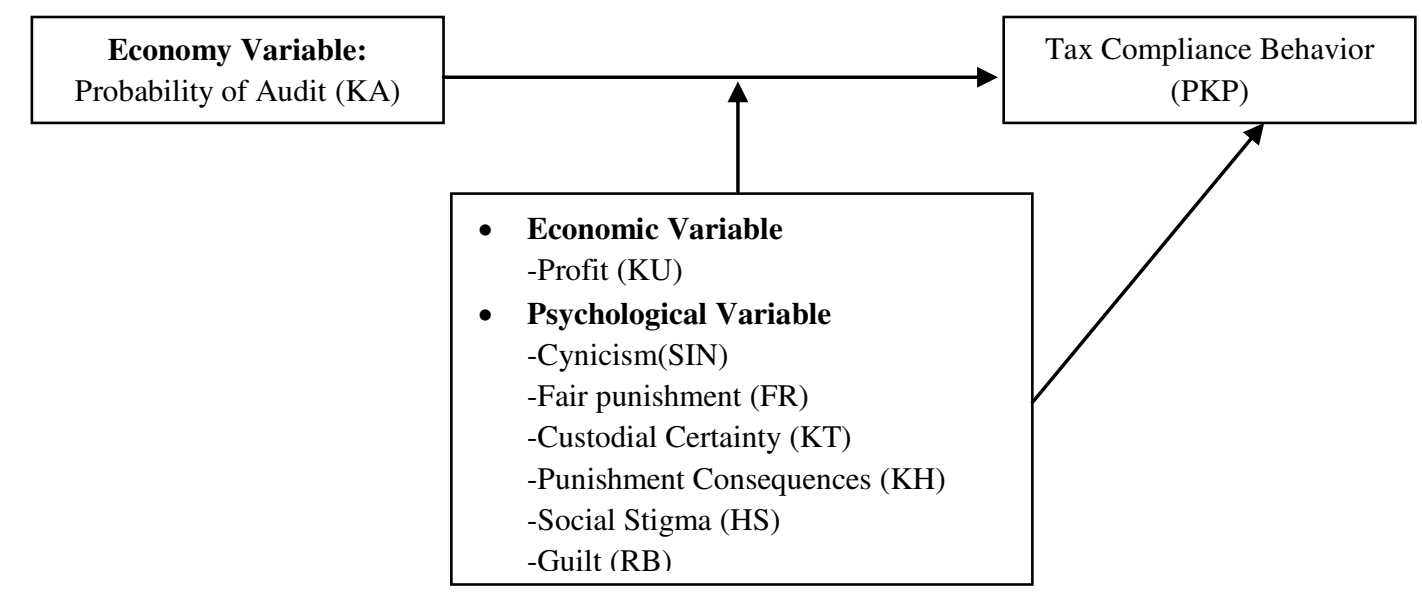

Figure 1. Research Model 
Table 2. Respondent General Description

\begin{tabular}{|c|c|c|}
\hline Characteristics & Total & Percentage \\
\hline \multicolumn{3}{|l|}{ Turnover } \\
\hline Lower than IDR 300.000 .000 ,- & 70 & $74,46 \%$ \\
\hline IDR $300.000 .001-$ IDR $2.500 .000 .000,-$ & 19 & $20,22 \%$ \\
\hline IDR $2.500 .000 .001,-$ IDR 4.800 .000 .000 & 5 & $5,32 \%$ \\
\hline Total & 94 & $100,00 \%$ \\
\hline \multicolumn{3}{|l|}{ Age } \\
\hline$\leq 30$ years old & 11 & $11,71 \%$ \\
\hline $31-40$ & 30 & $31,91 \%$ \\
\hline $41-50$ & 46 & $48,93 \%$ \\
\hline$\geq 51$ & 7 & $7,45 \%$ \\
\hline Total & 94 & $100,00 \%$ \\
\hline \multicolumn{3}{|l|}{ Type of Business } \\
\hline Warung Makan (Food Shop) & 53 & $33,90 \%$ \\
\hline Kelontong (Grocery) & 32 & $50,00 \%$ \\
\hline Others & 9 & $16,10 \%$ \\
\hline Total & 94 & $100,00 \%$ \\
\hline \multicolumn{3}{|l|}{ Age of Business } \\
\hline$\leq 5$ years & 53 & $56,38 \%$ \\
\hline $6-10$ & 22 & $23,40 \%$ \\
\hline $11-15$ & 12 & $12,77 \%$ \\
\hline$\geq 15$ & 7 & $7,45 \%$ \\
\hline Total & 94 & $100,00 \%$ \\
\hline Characteristics of Respondent & Total & Percentage \\
\hline \multicolumn{3}{|l|}{ Educational Backround } \\
\hline Junior High School & 47 & $50,00 \%$ \\
\hline Senior High School & 20 & $21,28 \%$ \\
\hline Diploma & 16 & $17,02 \%$ \\
\hline Bachelor or Postgraduate & 11 & $11,70 \%$ \\
\hline Total & 94 & $100,00 \%$ \\
\hline
\end{tabular}

Guilt (GUILT), including punishment that comes from within the individual himself, for example, feelings of guilt for being involved in illegal and criminal acts (Grasmick and Green, 1980); Beams et al., 2003). The instrument used to measure this variable was adopted from Beams et al. (2003).

\section{Statistic Testing Tool}

The statistical testing tool used to examine the influence of variables is multiple regression using SPSS or E-Views program. The regression equation of this research is:

$\mathrm{COM}=\alpha+\beta_{1} \mathrm{AU}+\beta_{2}$ GAIN $+\beta_{3}$ SINIS $+\beta_{1}$ FAIR $+\beta_{3}$ CERTAIN $+\beta_{6}$ PUNISH $+\beta_{7}$ STIGMA $+\beta_{8}$ GULIT + $\beta_{9} \mathrm{AU}^{*} \mathrm{GAIN}+\beta_{10} \mathrm{AU}^{*} \mathrm{SINIS}+\beta_{11} \mathrm{AU}^{*} \mathrm{FAIR}+$ $\beta_{12} \mathrm{AU}^{*}$ CERTAIN $+\quad \beta_{13} \mathrm{AU}^{*} \mathrm{PUNISH}^{+} \quad \beta_{1}$ $\mathrm{AU}^{*} \mathrm{STIGMA}+\beta_{15} \mathrm{AU}^{*}$ GUILT $+\mathrm{e}$

\section{RESULT AND DISCUSSION}

\section{Respondent General Description}

The population of respondents in this study is all MSME in Klaten District. The types of businesses that enter as the criteria of respondents include supermarkets selling daily needs, culinary business, store building, rental, printing, fashion, and tailor. This research was conducted by spreading the questionnaire and visiting MSME entrepreneurs. Based on the questionnaires obtained, the characteristics of respondents was based on turnover rate, member of MSME organization, gender, age, business type, business age, and latest education. The summary of the respondent general description is shown in Table 2.

\section{Questionnaire Rate of Return}

The number of questionnaires distributed was 150 . Questionnaire filled and returned as was 106. After the reliability test, the number of 
questionnaires could be used was 94, while the other 12 questionnaires are incomplete and there is existing data outlier. Questionnaire rate of return is described in Table 3.

Table 3. Questionnaire Rate of Return

\begin{tabular}{lrr}
\hline Information & Total & Percentage \\
\hline Distributed questionnaire & 150 & $100 \%$ \\
Returned questionnaire & 106 & $70,67 \%$ \\
Incomplete questionnaire & 5 & $3,33 \%$ \\
Questionnaires can be & 101 & $67,34 \%$ \\
processed early & & \\
Outlier Data & 7 & $4,67 \%$ \\
Questionnaire was analyzed & 94 & $62,67 \%$ \\
\hline
\end{tabular}

\section{Reliability Test}

The purpose of this reliability test is to determine accuracy and precision of a measurement procedure. The questionnaire is reliable or should one's response to a statement is consistent or stable over time (Ghozali, 2011). Research instrument reliability could be determined by the value of Cronbach's alpha. A question is said to be reliable if the Cronbach's alpha value is greater than 0.7. Nevertheless, 0.6 is still acceptable, whereas values below 0.6 are considered not reliable (Hair et al., 2014).

Table 4. Reliability Test

\begin{tabular}{lcl}
\hline Variable & $\begin{array}{c}\text { Cronbach's } \\
\text { alpha }\end{array}$ & Result \\
\hline Probability of Audit & 0,626 & Reliable \\
Profit & 0,732 & Reliable \\
Cynicism & 0,622 & Reliable \\
Fair Punishment & 0,629 & Reliable \\
Custodial certainty & 0,688 & Reliable \\
Punishment & 0,607 & Reliable \\
Consequences & & \\
Social Stigma & 0,611 & Reliable \\
Guilt & 1,000 & Reliable \\
Tax Compliance & 0,746 & Reliable \\
\hline
\end{tabular}

Table 5. KMO and Barlett's Test

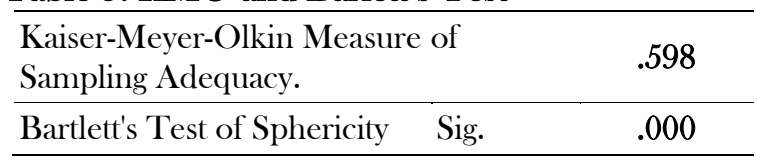

\section{Validity Test}

Test Validity in this study was conducted in two ways, the first correlate the score of each question item in each variable with the total score of each variable. The question item is said to be valid if it correlates to its total score significantly.
After validity test was conducted using correlation technique, validity test was also conducted using Factor Analysis technique. Factor analysis can be performed if KMO values are above 0.5 and significant (Hair et al., 2014). Based on the test results, $\mathrm{KMO}$ value of $0,598>0,50$ and sig 0,00 $<0,05$ were obtained. The value of KMO and its significance level is presented in Table 5. Based on the KMO test, it can be concluded that the factor analysis is feasible to be conducted. The next step is to test to determine eigen value which also determines how many factors are formed. Explanation of eigen value of each variable can be seen in Table 6.

Tabel 6. Eigen Value

\begin{tabular}{ccc}
\hline Factor & Eigenvalue & Total \% of Variance \\
\hline 1. & 8,669 & 26,269 \\
2. & 3,780 & 11,454 \\
3. & 2,685 & 8,136 \\
4. & 2,203 & 6,675 \\
5. & 1,627 & 4,929 \\
6 & 1,529 & 4,635 \\
7 & 1,325 & 4,015 \\
8 & 1,180 & 3,574 \\
9 & 1,120 & 3,405 \\
\hline
\end{tabular}

Table 7. Validity Test

\begin{tabular}{lc}
\hline Variable & Construct Validity \\
\hline Probability of Audit & AU2, AU10, AU11, \\
Profit & GAIN 1, GAIN 2 \\
Cynicism & SIN 1, SIN2 \\
Fair Punishment & FAIR1, FAIR2 \\
Custodial certainty & CER1 \\
Punishment & PU3, PU5 \\
Consequences & STIG1, STIG2 \\
Social Stigma & G1 \\
Guilt & COM1,COM4, COM8, \\
Tax Compliance & COM10, COM11 \\
\end{tabular}

The test revealed 9 factors. To determine the variables of each factor, it is necessary to test the validity of the construct. Test of construct validity was conducted by using Confirmatory Factor Analysis (CFA) method. Each item is said to be valid if a value having a factor loading value above 0.4 is considered more significant and 0.5 is considered significant (Hair et al., 2014). This factor analysis is confirmatory, i.e confirming the validity level of the question items in the questionnaire adopted from the previous study by making a slight modification with the adjustment to the research context. Questionnaires that do not meet requirements such as having more than one loading value on different factors, have a 
greater loading value on factors compared to their own factors or do not have a loading value on the factor to be eliminated. Question items that have a loading factor of less than 0.4 will also be excluded because they are considered to have only the ability to interpret a factor at a minimum level, whereas a question item that has a loading factor of 0.4 or $>0.4$ is acceptable and can be entered as a member of a factor. The end result of the construct validity test after the invalid item reduction with the CFA method was done on 94 respondents. Based on the results of factor analysis, then valid question items are presented in Table 7.

\section{Hypothesis Testing}

The data analysis technique used to test the hypothesis is Multiple Regression. The test was conducted in one step, which is to regress each independent variable to the dependent variable and including the interaction relationship. Нypothesis 1 in this study is expressed by the perception on probability of audit possessing positive effect on tax compliance behavior. Based on the Table 8 analysis, the coefficient of 2.228 with pvalue is $0.003<\alpha(0.05)$, therefore it can be concluded that hypothesis 1 in this study is accepted. In other words, the more likely a MSME will be audited, then the tax compliance level will increase.

Hypothesis 2 examines the direct relationships and interaction relationships between expected profit and perceptions on probability of audit and tax compliance behavior. Hypothesis $2 \mathrm{a}$ is expressed by a person's perception to gain profit negatively affect the tax compliance behavior. Based on the analysis of Table 8 , the value of coefficient of 0.354 and p-value is $0,579>\alpha(0,05)$, therefore it can be concluded that hypothesis $2 \mathrm{a}$ is not accepted. While hypothesis $2 \mathrm{~b}$ which states that the interaction between the probability of audit in the hope of obtaining profit negatively affect the tax compliance behavior is not accepted (coefficient of -0.06 and p-value> $\alpha 0.274$ ).

Hypothesis 3 examines the direct influence and interaction effects of cynicism and perception on probability of audit on tax compliance behavior. Hypothesis 3 a states that cynicism has a significant negative effect on tax compliance. Based on data analysis from table 8 obtained coefficient value of 2.273 and p-value of 0.025 . Although the results are significant the regression coefficient exhibits positive sign results, therefore hypothesis 3 a remains unaccepted. Hypothesis $3 \mathrm{~b}$ stated that the interaction between the probability of audit with cynicism will negatively affect the tax compliance behavior. Based on the analysis in table 8 , coefficient of -0.140 and p-value of $0.110>$ from $\alpha(0.00)$ were obtained, therefore it can be concluded that hypothesis $3 \mathrm{~b}$ is not accepted.

Hypothesis $4 \mathrm{a}$ is stated that perception of fair punishment has a significant positive effect on tax compliance. Based on the analysis of Table 8, the coefficient of -1.614 and p-value is 0,02 were obtained, therefore it can be concluded that hypothesis $4 \mathrm{a}$ is not accepted. While hypothesis $4 \mathrm{~b}$ is

Table 8. Hypothesis Testing Result

\begin{tabular}{|c|c|c|c|c|c|}
\hline Hypothesis & Variable & Direction & Coefficient & p-value & Result \\
\hline $\mathbf{H}_{1}$ & AU $->C O M$ & + & 2,228 & $0,003^{*}$ & Supported \\
\hline $\mathrm{H}_{2 \mathrm{a}}$ & GAIN $>$ COM & - & 0,354 & 0,579 & Not Supported \\
\hline $\mathrm{H}_{2 t}$ & SINIS ->COM & - & $-0,061$ & 0,274 & Not Supported \\
\hline$H_{3 x}$ & FAIR $>$ COM & - & 2,273 & 0,025 & Not Supported \\
\hline$H_{\mathrm{sb}}$ & CERT $->C O M$ & - & $-0,140$ & 0,110 & Not Supported \\
\hline $\mathrm{H}_{\text {ta }}$ & PUNISH ->COM & + & $-1,614$ & 0,029 & Not Supported \\
\hline $\mathrm{H}_{\mathrm{sb}}$ & STIGMA ->COM & + & 0,219 & $0,001^{*}$ & Supported \\
\hline $\mathrm{H}_{5 \mathrm{~s}}$ & GUILT $>$ COM & + & $-0,055$ & 0,960 & Not Supported \\
\hline $\mathrm{H}_{\mathrm{sb}}$ & $\mathrm{AU}^{*}$ GAIN $>\mathrm{COM}$ & + & $-0,006$ & 0,948 & Not Supported \\
\hline $\mathrm{H}_{\mathrm{ba}}$ & $\mathrm{AU}^{*} \mathrm{SINIS}$-> COM & + & 1,345 & 0,178 & Not Supported \\
\hline $\mathrm{H}_{\mathrm{bb}}$ & $\mathrm{AU}^{*} \mathrm{FAIR}->\mathrm{COM}$ & + & $-0,115$ & 0,193 & Not Supported \\
\hline $\mathbf{H}_{z_{a}}$ & AU ${ }^{\star}$ CERTAIN $>$ COM & + & 1,186 & $0,040^{*}$ & Supported \\
\hline $\mathrm{H}_{\mathrm{rb}}$ & AU*PUNISH -> COM & + & $-0,120$ & 0,014 & Not Supported \\
\hline$H_{s a}$ & AU*STIGMA -> COM & + & 0,020 & 0,991 & Not Supported \\
\hline$H_{s b}$ & $\mathrm{AU}^{*}$ GUILT $>\mathrm{COM}$ & + & 0,000 & 0,997 & Not Supported \\
\hline $\mathbf{R}$ square & & & & $68 \%$ & \\
\hline $\mathrm{N}$ & & & & 94 & \\
\hline
\end{tabular}


expressed by the interaction between probability of audit with the perspective of fair punishment has a positive effect on tax compliance. The analysis results in table 8 exhibits coefficient value of 0.219 and p-value of 0.001 . This result is in accordance with the proposed hypothesis, therefore hypothesis $4 \mathrm{~b}$ is accepted.

Hypothesis 5a stated custodial certainty have a significant positive effect on tax compliance. The result of data analysis exhibits coefficient value equal to $-0,055$ and $p$-value equal to $0,960>\alpha$ $(0,05)$, therefore it can be concluded that hypothesis $5 \mathrm{a}$ is not accepted. Hypothesis $5 \mathrm{~b}$ stated that interaction between probability of audit and custodial certainty having a significant and positive effect on tax compliance. The analysis results in Table 8 exhibits the coefficient value of -0.006 and p-value $0.948>\alpha$ (0.05). Therefore it can be concluded that hypothesis $5 \mathrm{~b}$ is not accepted.

Hypothesis six examines the effect of perception on probability of audit and tax compliance behavior moderated by the consequences of severe punishment. Based on the result of the data in Table 8, the value of coefficient 1,345 and pvalue $0,178>\alpha(0,05)$, therefore hypothesis 6 a which stated with severe punishment consequences having a significant positive effect to tax compliance is not accepted. While hypothesis $6 \mathrm{~b}$ stating that interaction between the probability of audit with severity of punishment consequences having a positive effect on tax compliance is not accepted (coefficient -0.115 with p-value $0.193>\alpha$ $0.00)$.

Hypothesis seven examines the effect of social stigma on tax compliance behavior and examines the effect of possible perception interaction with social stigma on tax compliance behavior. Based on analysis result in table 8 , the coefficient value of 1.186 and p-value $0.04<\alpha$ $(0.05)$ were obtained, therefore hypothesis $7 \mathrm{a}$ is accepted. While the hypothesis $7 \mathrm{~b}$ that examines the effect of interaction between perceptions on probability of audit and social stigma exhibits coefficient value of -0.120 and p-value $0,014<\alpha$ $(0.05)$. Therefore this hypothesis is not accepted despite being stated positive but test result exhibiting the negative direction.

Hypothesis 8a examines the influence of guilt on tax compliance behavior. Hypothesis $8 \mathrm{a}$ is stated that guilt has a significant positive effect on tax compliance behavior. The results of analysis in table 8 exhibits the coefficient value of 0.020 and p-value of 0.991 . Therefore it can be concluded that the hypothesis $8 \mathrm{a}$ in this study is not accepted.
Hypothesis $8 \mathrm{~b}$ is stated that interaction between guilt and probability of audit having a positive effect on tax compliance. The analysis results in Table 8 exhibit the coefficient value of 0.000 and p-value of $0.997>\alpha(0.05)$, therefore hypothesis $8 \mathrm{~b}$ is also not accepted.

Based on the results of this study, it can be concluded that there are several main factors that can improve tax compliance behavior. The government must frequently conduct audits on tax applicable entrepreneurs. The government must also apply a firm and fair punishment to the entrepreneurs who conduct tax evasion, social stigma is capable to provide deterrent effect to the perpetrators of tax evasion, punishment from the community or from the group usually last longer and it possesses long-term impact.

\section{CONCLUSION}

The purpose of this study is to examine the influence of economic and psychological variables in improving tax compliance. The probability of audit is an economic variable that can improve tax compliance. Psychological variables that can improve tax compliance are fair punishment and social stigma. Based on the results of this study, the probability of audit proved to increase the tax compliance. This is in line with conditions in the field. Therefore when the survey was conducted, the respondents were fears should the survey is a form of tax audit. Fair punishment is a moderating variable that can increase the level of tax compliance. In relation to this, many respondents gave opinions regarding tax evasion cases that were prevalent in Indonesia, they felt that so far the law applied to crack down tax evasion behavior was not clear. Social stigma or punishment from groups and surrounding communities proved to improve tax compliance behavior. Social stigma has been found to have significant deterrent effects (Grasmick and Green, 1980; Scott and Grasmick, 1981; Tittle, 1980).

Based on the results of this study, the government should frequently conduct an audit of tax applicable entrepreneurs, which are MSME entrepreneurs. The government should also impose firm and fair punishment to entrepreneurs who conduct tax evasion. Many respondents who do not know about $1 \%$ final tax on MSME, therefore the government ought to conduct more socialization on tax laws. Most respondents do not intend to not pay taxes, but fear if the tax paid is 
high. Then these respondents tend to be silent, and do not want to be asked about taxes. The low knowledge of the tax itself makes the respondents confused in determining the amount of tax to be paid.

\section{ACKNOWLEDGEMENT}

The completion of this research cannot be separated from the help of various parties, the first acknowledgement to God Almighty who has given all the blessings and gifts, the second acknowledgement to the Directorate of Research and Community Service Ministry of Research, Technology and Higher Education which has funded this research, so this research can be well resolved. Researcher acknowledges all academic community of Universitas Widya Dharma providing motivation and all parties involved in the completion of this research that can not be mentioned by one author.

\section{REFERENCES}

Ali, M. M., H. W. Cecil and J. A. Knoblett. 2001. The Effect of Tax Rates and Enforcement Policies on Taxpayer Compliance: A Study of Self- Employed Taxpayers. Atlantic Economic Journal, 29, 186-202.

Alm, J. and M. Mc Kee. 1998. Extending the Lessons of Laboratory Experiments on Tax Compliance to Managerial and Decision Economics. Managerial and Decision Economics, 19, 259-275.

Alm, J., B. R. Jackson, and M. Mc Kee. 1992. Estimating the Determinant of Taxpayer Compliance With Experimental Data. National Tax Journal, 45, 107-114.

Alm, J. 1988. Uncertain Tax Policies, Individual Behavior and Welfare. The American Economic Review, 27, 237- 245.

Alm, J., I. Sanchez., and Ana D. J. 1995. Economic and Non-economic Factors in Tax Compliance. KYKLOS, 48 (1), 8-18.

Asnawi, M., Baridwan, Z., Supriyadi, Nahartyo, E. 2009. Analisis Keputusan Kepatuhan Pajak: Strategi Audit Random, Perceived Probability of Audit and Pemahaman Etika Pajak. Paper was Presented in Simposium Nasional Akuntansi XII, Palembang.

Chung, J., and V. U. Trivedi. 2003. The Effect of Friendly Persuasion and Gender on Tax
Compliance Behavior. Journal of Business Ethics, 47, 133-145.

Beams, J. D., M. B. Robert and N. K. Larry. 2003. An Experimental Testing the Determinants of Non-Compliance with Insider Trading Laws. Journal of Business Ethics, 45, 309-323.

Beck, P. J., J. S. Davis, and W. Jung. 1991. Experimental Evidence on Taxpayer Reporting Under Uncertainty. The Accounting Review, 66 (3), 535-558.

Blumenthal, M., C. Christian, and J. Slemrod. 2001. Do Normative Appeals Affect Tax Compliance? Evidence from a Controlled Experiment in Minnesota. National Tax Journal, 54 (1), 125-138.

Bobek, D., Donna, Charles F. Kelliher, and Amy M. Hageman. 2013. Analyzing the Role of Social Norms in Tax Compliance Behavior. Journal of Business Ethics.115:451-468.

Grasmick, H. G. and D. E. Green. 1980. Legal Punishment: Social Disapproval and Internalization as Inhibitors of Illegal Behavior. Journal of Criminal Law and Criminology, 71, 325-335.

Harinurdin, E. 2009. Perilaku Kepatuhan Wajib Pajak Baand, Bisnis \& Birokrasi. Jurnal Ilmu Administrasi and Organisasi, Jurnal Ilmu Administrasi dan Organisasi, 16 (2), 96-104.

Mason, R. and L. D. Calvin. 1984. Public Confidence and Admitted Tax Evasion. National Tax Journal, 37, 489-496.

Milliron, V. C., and D. R. Toy. 1988. Tax Compliance: An Investigation of Key Features. The Journal of the American Taxation Association, 9 (1), 84-104.

Salter, S. B., D. M. Guffey and J. J. McMillan. 2001. Truth, Consequences and Culture: A Comparative Examination of Cheating and Attitudes about Cheating among U.S. and U.K. Students. Journal of Business Ethics, 31, 37-50.

Scott, W. J. and H. G. Grasmick. 1981. Deterrence and Income Tax Cheating: Testing Interaction Hypothesis in Utilitarian Theories. The Journal of Applied Behavioral Science, 17 (3), 395-408. 